\title{
СОЗДАНИЕ И ВНЕДРЕНИЕ В КЛИНИЧЕСКУЮ ПРАКТИКУ НОВОЙ ТЕХНОЛОГИИ "ОБЛАКО ПОДДЕРЖКИ": ДИСТАНЦИОННОЕ МЕДИЦИНСКОЕ СОПРОВОЖДЕНИЕ ДЕТЕЙ С МАНИФЕСТАЦИЕЙ САХАРНОГО ДИАБЕТА 1 ТИПА С ИСПОЛЬЗОВАНИЕМ ТЕЛЕМЕДИЦИНСКИХ ТЕХНОЛОГИЙ
}

\author{
Кияев А.В., Полякова В.М., Асташова Е.С., Промин И.А., Словак М.А., Полляк О.Ю., Черных Л.Г., \\ Кожевникова О.В. \\ ${ }^{1 г а у з ~ С в е р д л о в с к о и ̆ ~ о б л а с т и ~ « О б л а с т н а я ~ д е т с к а я ~ к л и н и ч е с к а я ~ б о л ь н и ц а », ~ Е к а т е р и н б у р г ~}$ \\ ${ }^{2}$ ФГБОУ ВО «Уральский государственный медицинский университет» Минздрава России, Екатеринбург \\ ${ }^{3}$ Областной иентр детской эндокринологии, Екатеринбург
}

Ежегодно более 200 детей с манифестацией сахарного диабета 1 типа госпитализируются в отделение эндокринологии ГАУЗ СО «ОДКБ» (в 2020 году - впервые заболели СД1 229 детей), где им оказывается высококвалифицированная специализированная медицинская помощь, а также профессиональное обучение в «Школе диабета» (пациентам вместе с их законными представителями даются основы жизни с диабетом в течение 6 занятий), подбирается схема пожизненной заместительной инсулинотерапии и через 8-10 дней их выписывают домой. Вместе с тем, вне стен больницы, уже с первых дней пребывания в домашних условиях, семья ребенка, впервые заболевшего сахарным диабетом, продолжает испытывать множество серьезнейших проблем, связанных с адаптацией к болезни и адекватной коррекцией инсулинотерапии, особенно в течение первого года после манифестации - самого критического этапа жизни ребенка с СД. В этот период закладывается информация о колебаниях уровня глюкозы в так называемую «метаболическую память», которая может вносить свой существенный негативный вклад в раннее развитие хронических микрососудистых осложнений диабета. Кроме того, в течение первого года болезни, при неадекватном проведении самоконтроля гликемии и коррекции инсулинотерапии, значительно повышен риск развития острых осложнений диабета (тяжелые гипогликемии и диабетический кетоацидоз) - основных причин инвалидизации и смертности детей с сахарным диабетом.

Особую актуальность эти проблемы приобрели на фоне пандемии новой короновирусной инфекции, в связи с возникшими проблемами доступности оказания плановой медицинской помощи. В этих сложных условиях, сотрудники Областного Центра детской эндокринологии продолжали оказывать необходимую медицинскую помощь и удаленную поддержку детям с сахарным диабетом, и, вместе с врачами ординаторами-детскими эндокринологами Уральского Государственного Медицинского Университета, в течение 4 месяцев отрабатывали наиболее оптимальную модель дистанционного медицинского сопровождения детей с применением простых и доступных информационных технологий. Были отработаны формат, режим, продолжительность консультаций, разработан электронный дневник самоконтроля за сахарным диабетом. На этом этапе было проведено более 100 консультаций детей, впервые заболевших СД1 и выписанных из отделения эндокринологии. Затем проведено анкетирование родителей, участвовавших в проекте, а после получения их позитивных отзывов о жизненной необходимости этой технологии, встала задача реализовать эту технологию на защищенной телемедицинской платформе с соблюдением законности и порядка, регламентируемого Приказом Министерства здравоохранения РФ от 30 ноября 2017 г. N 965н «Об утверждении порядка организации и оказания медицинской помощи с применением телемедицинских технологий».

ЦЕЛЬ СОЗДАНИЯ И ВНЕДРЕНИЯ ТЕХНОЛОГИИ: ПОВЫшеНИе Качества И продоЛЖИтеЛЬНОстИ ЖИЗНИ детей с сахарным диабетом 1 типа.

С октября 2020 года, благодаря совместным усилиям сотрудников ОЦДЭ, медицинского информационно-аналитического центра МЗ СО, всеобъемлющей технической поддержки со стороны разработчиков медицинской информационной системы (Единая цифровая платформа), правообладателями телемедицинской платформы «Электронный доктор», а также специалистов ТФОМС (введены специальные тарифы на ТМК), в клиническую практику была внедрена уникальная технология, аналогов которой пока нет в России. 
Суть проекта состоит в оказании дистанционных медицинских консультаций в формате «врач-пациент» в режиме реального времени или в режиме отложенных консультаций на защищенной телемедицинской платформе (все участники процесса проходят идентификацию и аутентификацию через ЕПГУ) в рамках реализации программы государственных гарантий. Уже с первых дней после выписки из стационара (и далее - по необходимости), по запросу законного представителя ребенка с сахарным диабетом, состоящего на учете в ОЦДЭ, врач может назначить и провести телемедицинскую консультацию пациента, имеющего доступ к персональному компьютеру или смартфону, независимо от его местоположения, а также устойчивую работу сети интернет. Во время видео-консультации врач изучает электронный дневник самоконтроля ребенка и, при наличии, графики непрерывного мониторирования уровня глюкозы (имеется техническая возможность прикрепить файл любого формата в строку чата в момент соединения), обсуждает с законным представителем вопросы питания, физической активности (продолжая непрерывное индивидуальное обучение в «Школе диабета»), может осмотреть через веб-камеру места инъекций инсулина, и, в заключении, оформляет протокол телемедицинской консультации с рекомендациями по коррекции дозы инсулина, подписывая его усиленной квалифицированной цифровой подписью. Фактически, в момент телемедицинской консультации происходит имитация очного приема детского эндокринолога, с тем только отличием, что законный представитель приводит ребенка в «облачный» кабинет врача, при этом не выходя из дома. 